\begin{tabular}{rl|l}
$\begin{array}{c}\text { Cellular Physiology } \\
\text { and Biochemistry }\end{array}$ & Cell Physiol Biochem 2012;30:173-186 & \multicolumn{2}{l}{ DOI: 10.1159/000339056 } & $\begin{array}{l}\text { O 2012 S. Karger AG, Basel } \\
\text { www.karger.com/cpb }\end{array}$ \\
\cline { 2 - 3 } & $\begin{array}{l}\text { Published online: June 18, 2012 } \\
\text { Accepted: May 18, 2012 }\end{array}$ & $1015-8987 / 12 / 0301-0173 \$ 38.00 / 0$
\end{tabular}

\title{
Inhibitory Effect of IL-1 $\beta$ on Galactose Intestinal Absorption in Rabbits
}

\author{
Carmen Viñuales $^{a}$ Sonia Gascón ${ }^{a, c}$ Cristina Barranquero ${ }^{b, c}$ Jesús Osada ${ }^{b, c}$ \\ $M^{a}$ Jesús Rodríguez-Yoldia,
}

aUnidad de Fisiología, Departamento de Farmacología y Fisiología, bUnidad de Bioquímica,

Departamento de Bioquímica y Biología Molecular. Facultad de Veterinaria. Universidad de Zaragoza,

Zaragoza, 'CIBER de Fisiopatología de la Obesidad y Nutrición (CIBERobn), Instituto de Salud Carlos III

(ISCIII), Spain

Key Words

Galactose $\cdot$ Gut $\bullet$ IL-1 $\beta \cdot$ Kinases $\cdot$ Rabbit

\begin{abstract}
Background/Aims: Recent studies from our laboratory have shown that nitric oxide is involved in the IL-1 $\beta$-induced inhibition of D-fructose intestinal transport in rabbits. The aim of this work was to further the studies of IL- $1 \beta$ effect on D-galactose absorption in a septic state induced by intravenous administration of this cytokine. Methods: Galactose intestinal absorption was assessed employing three techniques: sugar uptake in jejunum everted rings, transepithelial flux in Ussing-type chambers and uptake assays in brush border membrane vesicles. The level of the $\mathrm{Na}^{+} / \mathrm{D}$-glucose cotransporter (SGLT1) expression was analyzed by Western blot. Results: In sepsis condition the body temperature was increased and studies on cellular intestinal integrity have not shown modifications in the brush border membrane. However, D-galactose absorption across mucosa of jejunum was diminished in IL-1 $\beta$ treated rabbits. The levels of SGLT-1 were no significantly different in both animal groups (control and IL-1 $\beta$ treated), indicating that the cytokine could induce a reduction in the SGLT-1 functionality. The inhibition was significantly reversed by the activation of several PKC, PKA, MAPKs and

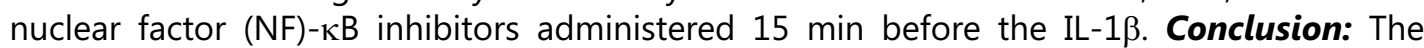
inhibitory effect of IL-1 $1 \beta$ on D-galactose absorption across mucosal side of enterocyte could be mediated by the activation of several kinases and nuclear factor (NF)- $\mathrm{kB}$.

Copyright (C) 2012 S. Karger AG, Basel

M.J. Rodríguez-Yoldi

Unidad de Fisiología, Facultad de Veterinaria. Universidad de Zaragoza

CIBER de Fisiopatología de la Obesidad y Nutrición (CIBERobn)

Instituto de Salud Carlos III (ISCIII)

Miguel Servet 177, 50013-Zaragoza (Spain)

E-Mailmjrodyol@unizar.es
\end{abstract}




\section{Cellular Physiology Cell Physiol Biochem 2012;30:173-186 \\ \begin{tabular}{ll|l} 
and Biochemistry & $\begin{array}{l}\text { DOI: 10.1159/000339056 } \\
\text { Published online: June 18, 2012 }\end{array}$ & $\begin{array}{l}\text { C 2012 S. Karger AG, Basel } \\
\text { www.karger.com/cpb }\end{array}$ \\
\cline { 2 - 3 } $\begin{array}{l}\text { Viñuales/Gascón/Barranquero/Osada/Rodríguez-Yoldi: IL-1 } \beta \text { on Galactose Intestinal } \\
\text { Absorption }\end{array}$
\end{tabular}}

\section{Introduction}

The intestinal mucosal barrier plays an important role in the body's protection against luminal pathogens and antigenic molecules. The intestinal barrier includes secreted mucus and the epithelial cell lining the digestive tract, which serves as a selective barrier permitting the uptake of nutrients, ions and other desired solutes, thus helping to maintain homeostasis of the internal environment. Pathological events such as intestinal inflammation and sepsis cause impairment of the intestinal epithelial barrier. Therefore, bacteria and their lytic products, such as lipopolysaccharide, gain access to the portal and systemic circulations inducing systemic inflammatory response syndrome or even multiple organ dysfunction syndrome. In these conditions increases in cytokine concentrations are well documented [1-3].

During inflammatory states, interleukins (ILs) regulate the intensity of the intestinal immune response and mediate altered physiology in response to the inflammatory process either directly or via production of additional effector molecules that play a central role in the intestinal inflammation amplification cascade. Aside from their role in the regulation of the immune cascade, interleukins have also been shown to modulate intestinal transport function [4].

IL- 1 consists of three members: IL- $1 \alpha$, IL-1 $\beta$, and IL-1 receptor antagonist (IL-1ra) [5]. IL- $\beta$ is secreted into surrounding interstitial fluid and blood circulation during inflammation and mediates wide-ranging proinflammatory actions [6]. IL-1 $\beta$ was originally identified as the endogenous pyrogen, and if exogenously administered, it causes fever in experimental animals [7]. IL-1 $\beta$ has been shown to play an important role in the pathogenesis of gut diseases (vg Inflammatory Bowel Disease, IBD) and in animal models of intestinal inflammation [5, 8]. In these cases, the level of IL-1 $\beta$ was found increased [9]. In vitro studies have shown that Il-1 $\beta$ causes an increase in intestinal epithelial tight junction permeability in Caco- 2 cells [4] and inhibits D-galactose [10] and 3-o-methylglucose [11] intestinal absorption in rats. This cytokine stimulates anion secretion in chicken intestine [12], while the IL- $\alpha$ has been reported to inhibit $\mathrm{Na}^{+}$and $\mathrm{Cl}^{-}$absorption [13] and to increase 3-o-methyl glucose jejunal in vitro absorption in rabbits [14].

In this work, the rabbit has been used as an experimental model to characterize the multiple biological properties of IL- $1 \beta$ and to investigate its involvement in the pathogenesis of several immunological and inflammatory diseases. Our laboratory has recently shown that nitric oxide is involved in the IL- $1 \beta$-induced inhibition of D-fructose intestinal transport using a rabbit model of sepsis [15]. In order to better characterize the mode of action of IL$1 \beta$ on sugar intestinal absorption in vivo, we studied the handling of D-galactose in normal and treated animals. The knowledge of the regulation of IL-1 $\beta$ action may help to adopt strategies to protect and treat animals in sepsis state.

\section{Materials and Methods}

\section{Materials}

D-galactose, D-mannitol, Hepes, Tris (hydroxymethyl) amino-methane, sucrase, albumin bovine, adenosine $5^{\prime}$-triphosphate (ATP), protein kinase inhibitor ( $\left.\mathrm{IP}_{20}\right)$ and anti-actin were obtained from Sigma. Interleukin 1- $\beta$ recombinant human was obtained from PeproTech GmbH. Bisindolylmaleimide I hydrochloride (GF-109203X) and Carbobenzoxy-L-leucyl-L-leucinal (MG-132) were from Calbiochem. 4[5-(4-Fluorophenyl)-2-[4-(methylsulphonyl)phenyl]-1H-imidazol-4-yl]pyridine hydrochloride (SB-203580 hydrochloride), anthra[1-9-cd]pyrazol-6(2H)-one (SP-600125), 1,4-diamino-2,3-dicyano-1,4-bis[2aminophenylthio]butadiene (U-0126) and 5,7-Dihydroxy-3-(4-hydroxyphenyl)-4H-1-benzopyran-4-one (Genistein) were supplied by Tocris. LY-294002 was obtained from Stressgen. D-[U- $\left.{ }^{14} \mathrm{C}\right]$ galactose, anti-rabbit IgG peroxidase and Biodegradable Counting Liquid Scintillation were obtained from GE Healthcare Life Sciences. The membrane filters were obtained from Millipore. The reagents used in Western blot analysis were obtained from Bio-Rad, Sigma and Serva. 


\section{Cellular Physiology $\quad$ Cell Physiol Biochem 2012;30:173-186

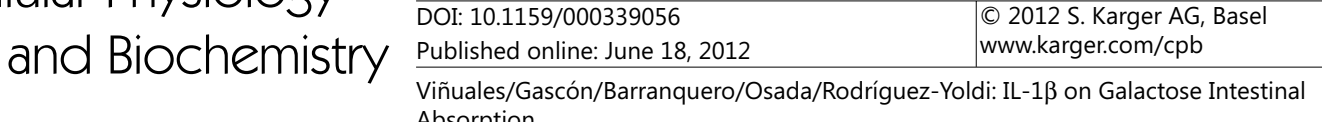 Absorption}

Animals, preparation of intestinal tissue

The experimental animals were housed, handled, and euthanized according to European Union Legislation 86/609/EEC. All experimental protocols were approved by the Ethics Committee of the University of Zaragoza (PI47/10). Male New Zealand rabbits weighing 1.8-2.0 kg were maintained at constant room temperature $\left(24^{\circ} \mathrm{C}\right)$ with free access to water and standard rabbit fodder $(25.1 \%$ proteins, 3.8\% fat, $18.05 \%$ cellulose). Two experimental groups were made. One group of rabbits received an intravenous (iv) solution of $200 \mu \mathrm{l} \mathrm{IL-1 \beta}$ (treated animals), and the other received $200 \mu \mathrm{l}$ saline solution (control animals). Rabbits were killed $90 \mathrm{~min}$ after injection, following previously published protocols including ours [15-19] and intestinal samples were taken. The protein inhibitors were injected 15 min before IL-1 $\beta$ and the dose was calculated from published EC50 in relation to body weight. It was administered in a final volume of $200 \mu \mathrm{l}$ to avoid any changes in blood volume. Vehicle used $(200 \mu \mathrm{l})$ was saline solution (IP20, GF-109203X, SB2033580) or DMSO (LY-294002, Genistein, SP-600125, U-0126, MG-132). The animal treatment with saline solution or DMSO before IL-1 $\beta$ had no effect.

After euthanasia, the proximal jejunum was removed and rinsed with ice-cold Ringer's solution which contained (in mM): $140 \mathrm{NaCl}, 10 \mathrm{KHCO}_{3}, 0.4 \mathrm{KH}_{2} \mathrm{PO}_{4}, 2.4 \mathrm{~K}_{2} \mathrm{HPO}_{4}, 1.2 \mathrm{CaCl}_{2}$ and $1.2 \mathrm{MgCl}_{2}, \mathrm{pH} 7.4$.

\section{Sugar uptake measurements}

Tissue uptake. Rings of everted jejunum weighing about $100 \mathrm{mg}$ were continuously bubbled with $95 \%$ $\mathrm{O}_{2}-5 \% \mathrm{CO}_{2}$. Tissue rings were incubated for $3 \mathrm{~min}$ in Ringer's solution at $37^{\circ} \mathrm{C}$ containing $0.01 \mu \mathrm{Ci} \mathrm{ml}{ }^{-1} \mathrm{D}$ $\left[\mathrm{U}^{-14} \mathrm{C}\right]$ galactose plus 0.5 or $10 \mathrm{mM}$ unlabeled substrate. After incubation, tissue pieces were washed with three gentle shakes in ice-cold Ringer's solution and blotted carefully on both sides to remove excess of solution, weighed, and incubated overnight in $0.5 \mathrm{ml}$ of $0.1 \mathrm{M} \mathrm{HNO}_{3}$ at $4^{\circ} \mathrm{C}$ to extract the labeled sugar from tissue. Aliquots of $200 \mu \mathrm{l}$ from extract and bathing solutions were counted in $2 \mathrm{ml}$ of scintillation fluid. The measurements were expressed as $\mu \mathrm{mol}$ of D-galactose per gram of tissue.

Transepithelial flux measurements. The jejunum was stripped of its serosal and external muscle layers and mounted as a flat sheet in Ussing-type chambers. The bathing solutions on the mucosal and serosal tissue surfaces were maintained at $37^{\circ} \mathrm{C}$ with the help of a circulating water bath. D-galactose concentrations were the same in both solutions (1 mM). Mucosal to serosal sugar fluxes (Jm-s) were measured by adding $0.04 \mu \mathrm{Ci} \mathrm{ml}{ }^{-1} \mathrm{D}-\left[\mathrm{U}-{ }^{14} \mathrm{C}\right]$ galactose to the mucosal side, and serosal to mucosal fluxes (Js-m) by placing the D$\left[\mathrm{U}-{ }^{14} \mathrm{C}\right]$ galactose on the serosal side. Samples were removed from the non-radioactively labelled side at 20 min intervals for $60 \mathrm{~min}$, after a $40 \mathrm{~min}$ preincubation period. Only one sample was taken for counting from the radioactively labelled side. Samples of the radioactive solution were counted using a liquid scintillation counter. Results are expressed as $\mu \mathrm{mol}$ D-galactose $\mathrm{cm}^{-2} \mathrm{~h}^{-1}$.

$\mathrm{Na}^{+} / \mathrm{K}^{+}$-ATPase activity measurement in basolateral membrane vesicles (BLMV). $\mathrm{Na}^{+} / \mathrm{K}^{+}$-ATPase is an enzyme located in the basolateral membrane of the enterocytes. BLMV were prepared from intestinal tissue as previously described [19]. The results of $\mathrm{Na}^{+} / \mathrm{K}^{+}$-ATPase activity are expressed as specific activity (SA), which is defined as nanomols of Pi liberated from substrate hydrolyzed per milligram of protein per minutes at $37^{\circ} \mathrm{C}$. The purity of the basolateral membrane preparations was determined by the measurement of the enzymatic activity of sucrase, an enzyme located in the brush border membrane.

BBMV uptake assays. Brush border membrane (BBM) vesicles (BBMVs) were prepared using the $\mathrm{Mg}^{2+}$ EGTA precipitation method. Prepared BBMVs containing $300 \mathrm{mM}$ mannitol and $10 \mathrm{mM}$ HEPES-Tris pH 7.4 buffer were used for transport studies. Protein content was measured with the Bradford method using bovine serum albumin as standard. BBMV purity was determined by measuring sucrase activity enrichments and levels of basolateral plasma membranes were assayed by measuring $\mathrm{Na}^{+} / \mathrm{K}^{+}$-ATPase activity.

Galactose uptake was measured at different time points: 5, 10, 40, $60 \mathrm{~s}$ and $120 \mathrm{~min}$. Incubations were performed at $37^{\circ} \mathrm{C}$ and started by adding $5 \mu \mathrm{l}(200 \mu \mathrm{g})$ of BBMV to $45 \mu \mathrm{l}$ of incubation medium containing $10 \mathrm{mM}$ Hepes-Tris, $100 \mathrm{mM} \mathrm{NaCl}, 0.01 \mu \mathrm{Ci} \mathrm{ml}^{-1} \mathrm{D}-\left[\mathrm{U}-{ }^{14} \mathrm{C}\right]$ galactose plus $0.1 \mathrm{mM}$ unlabelled substrate, and $\mathrm{D}-$ mannitol to compensate for osmolarity (300 mosmol per l). The results are expressed as D-galactose uptake in picomols per milligram protein.

\section{Western blotting}

Similar amounts of BBMVs protein $(10 \mu \mathrm{g})$ from control and treated animals were solubilized in Laemmli sample buffer and resolved by $10 \%$ SDS-PAGE. Proteins were transferred onto PVDF membranes by use of a semidry transblot transfer apparatus (Bio-Rad). The protein transfer efficiency was visualized with Ponceau S and by the transfer of Rainbow molecular weight markers (Sigma). SGLT1 was detected by using a 


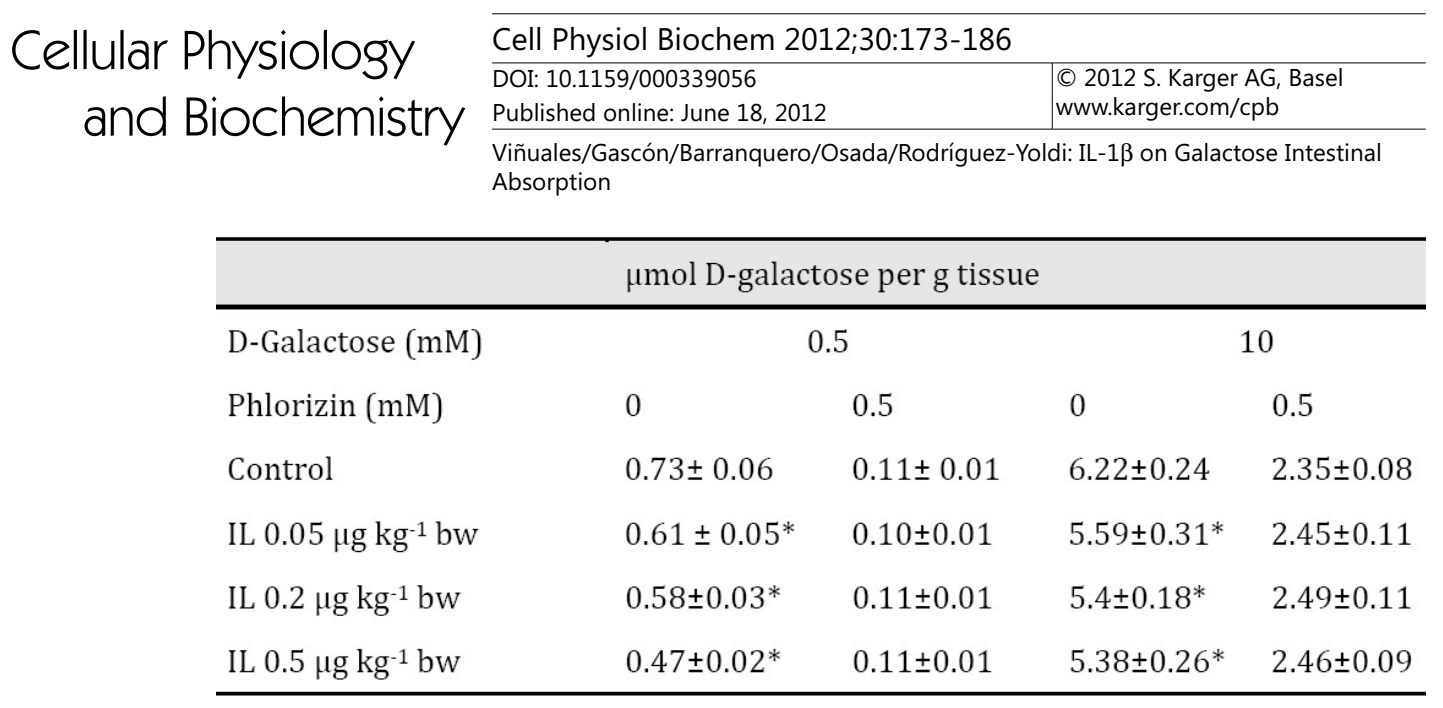

Table 1. Effect of IL-1 $\beta$ on 0.5 and $10 \mathrm{mM}$ D-galactose absorption when $0.5 \mathrm{mM}$ phlorizin was added to the medium. Each value represents the mean and SEM of the data obtained in six animals with six determinations per animal. ${ }^{*} p<0.05$ with respect to the control animals.

\begin{tabular}{lccc}
\hline Conditions & $\begin{array}{c}\text { Initial } \\
\text { temperature }\left({ }^{\circ} \mathrm{C}\right)\end{array}$ & $\begin{array}{c}\text { Final } \\
\text { temperature }\left({ }^{\circ} \mathrm{C}\right)\end{array}$ & $\begin{array}{c}\text { Increase } \\
\text { temperature }\left({ }^{\circ} \mathrm{C}\right)\end{array}$ \\
\hline Control & $38.8 \pm 0.24$ & $38.7 \pm 0.18$ & $\cdots-$ \\
$\mathrm{IL}-1 \beta$ & $38.5 \pm 0.06$ & $40.3 \pm 0.08^{*}$ & 1.8 \\
\hline
\end{tabular}

Table 2. Effect of $0.5 \mu \mathrm{g} \mathrm{kg}^{-1}$ bw IL-1 $\beta$ on body temperature. The rectal temperature was measured every 30 minutes for 90 minutes. The results are from 6 animals at each condition. ${ }^{*} p<0.05$ with respect to the control animals.

rabbit polyclonal anti-SGLT1 antibody (D01P, Abnova; 1:250 dilution). Equal loading was confirmed by using actin as reference and evidenced with a rabbit anti-actin antibody (Sigma, 1:2500 dilution). Detection was carried out using an anti-rabbit IgG conjugated to horseradish peroxidase (Amersham, 1:10000 dilution) and ECL chemiluminescence (GE Healthcare). Membranes were exposed to ECL films (GE Healthcare) for several time periods to achieve signal intensity within the dynamic range of quantitative detection, and films were scanned at a 600-dpi resolution (via AGFA Arcus II). Density of SGLT1 bands for each condition, taken as volume of pixels per square millimeter, was calculated using Quantity One software version 4.5.0. (BioRad) and normalized to that corresponding the actin signal.

\section{Statistical Analysis}

All results are expressed as means \pm SE. Means were compared using an one-way analysis of variance (ANOVA). Significant differences at $p<0.05$ were compared using a Bonferroni's Multiple Comparison Test. The statistical analysis and the graphics were performed using the GraphPad Prism Version 5.02 program on a PC computer.

\section{Results}

Dose-dependent effect of $I L-1 \beta$ on galactose intestinal absorption

We studied the effect of iv administration of IL-1 $1 \beta\left(0.05 ; 0.2\right.$ and $0.5 \mu \mathrm{g} \mathrm{kg}^{-1}$ body weight -bw-) on the intestinal absorption of D-galactose 0.5 and $10 \mathrm{mM}$. Following $90 \mathrm{~min}$ of cytokine treatment, the animals were sacrificed and the sugar intestinal uptake was measured (3 min incubation). As shown in Table 1, all assayed concentrations inhibited the D-galactose absorption. For the following experimental studies we chose the concentration $0.5 \mu \mathrm{g} \mathrm{kg}^{-1}$ which inhibits the 0.5 and $10 \mathrm{mM}$ sugar absorption about 35 and $13 \%$ respectively.

\section{Sepsis evoked by IL-1ß intravenous administration}

To evaluate the septic state evoked by IL- $1 \beta$ at dose of $0.5 \mu \mathrm{g} \mathrm{kg}^{-1} \mathrm{bw}$, the body temperature was recorded. A significant increase (about $1.8^{\circ} \mathrm{C}$ ) in rectal temperature was reported 90 min after IL injection (Table 2). Despite this fact, studies on cellular intestinal integrity, by 


\section{Cellular Physiology $\quad$ Cell Physiol Biochem 2012;30:173-186

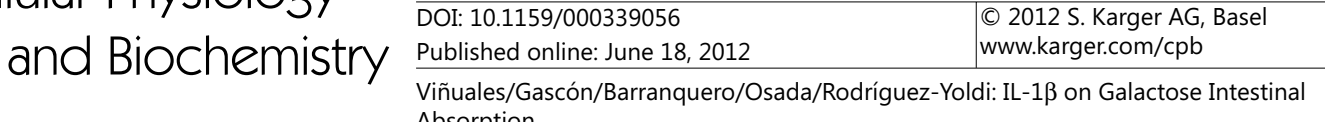

A

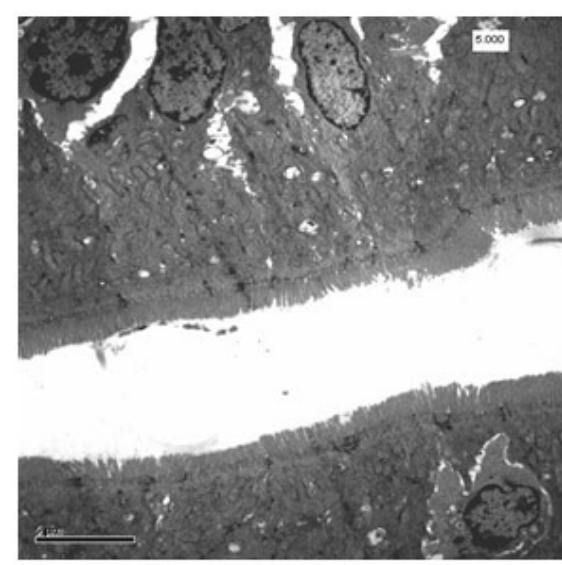

B

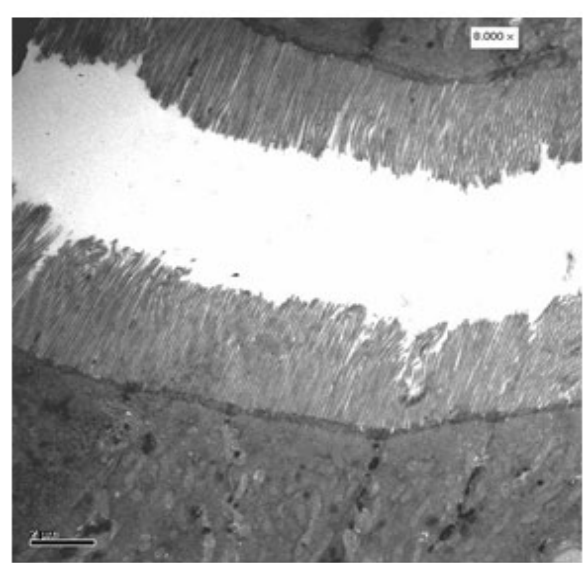

Fig. 1. Electron microscopy image of small intestine (microvilli) from control and treated rabbits with 0.5 $\mu \mathrm{g} \mathrm{kg}{ }^{-1}$ IL-1 $\beta$ bw for 90 min. a) Control jejunum at $5000 \times$ magnification. Bar denotes $5 \mu \mathrm{m}$. b) Corresponds to jejunum of treated animals at $8000 \mathrm{x}$ magnification. Bar corresponds to $2 \mu \mathrm{m}$.

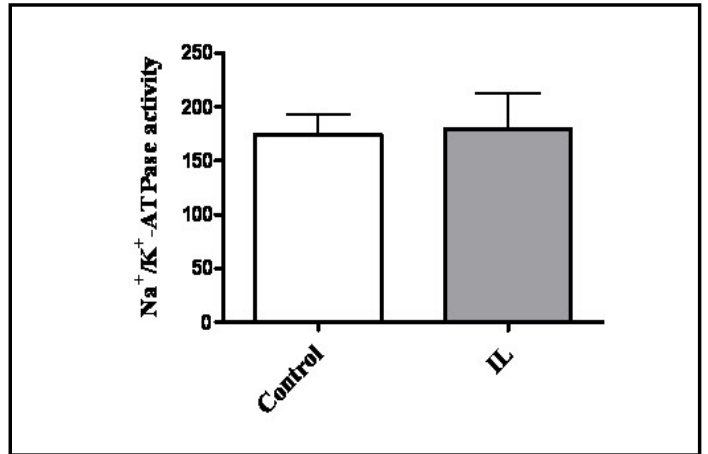

Fig. 2. Specific activity of $\mathrm{Na}^{+} / \mathrm{K}^{+}$-ATPase (nmol Pi per mg protein per min) in basolateral membranes of enterocytes from control and treated $\left(0.5 \mu \mathrm{g} \mathrm{kg}^{-1} \mathrm{bw}\right.$ Il-1 $\beta$ for $90 \mathrm{~min}$ ) animals. Each value represents the mean and SEM of the data obtained in six animals.

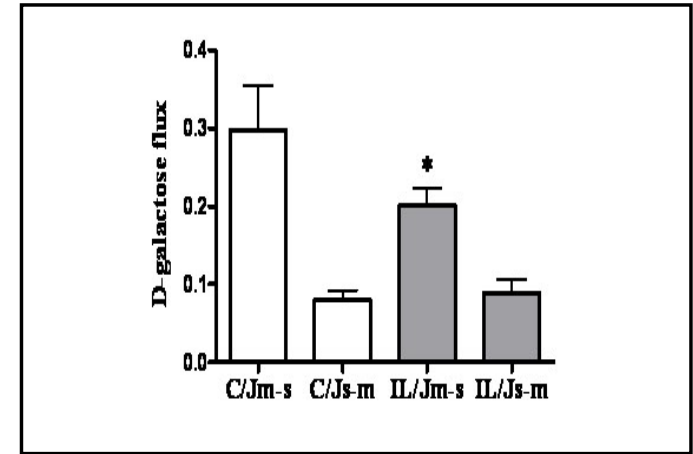

Fig. 3. Effect of $0.5 \mu \mathrm{g} \mathrm{kg}^{-1}$ bw Il-1 $\beta$ for $90 \mathrm{~min}$ on $1 \mathrm{mM}$ D-galactose mucosal to serosal (Jm-s) and serosal to mucosal (Js-m) fluxes. The results are expressed as $\mu$ mol D-galactose $\mathrm{cm}^{-2} \mathrm{~h}^{-1}$. Each value represents the mean and SEM of the data obtained in six animals with eight determinations per animal. ${ }^{*} p<0.05$ compares results obtained in treated with control.

Electron Microscopy analysis, have not shown modifications in the brush border membrane (Fig. 1a, b). All together these results indicate that IL-1 $\beta$ injection induced a septic state in rabbits without morphological modification in the mucosal membrane of enterocytes.

\section{IL-1 $\beta$ effect on galactose intestinal absorption.}

Studies on intestinal tissue. The transport of D-galactose across the brush border membrane of the intestine is carried out by $\mathrm{Na}^{+}$-dependent system and simple diffusion. To further characterize the action of IL-1 $\beta$, the D-galactose uptake (3 min of incubation) was measured at two concentrations of sugar $(0.5$ and $10 \mathrm{mM})$ in presence or absence of $0.5 \mathrm{mM}$ phlorizin. The beta-glucoside phlorizin is a potent competitive inhibitor of $\mathrm{Na}^{+}-$ glucose transport [20]. The results showed that IL-1 $\beta\left(0.5 \mu \mathrm{g} \mathrm{kg}^{-1}\right)$ significantly diminishes D-galactose uptake and that the cytokine did not change either 0.5 or $10 \mathrm{mM}$ D-galactose absorption in presence of this glucoside (Table 1). These results indicate that IL-1 $\beta$ does not modify sugar simple diffusion and that the cytokine inhibits the intestinal D-galactose transport due to an effect mainly located on the $\mathrm{Na}^{+}$-dependent system of transport at the 


\begin{tabular}{|c|c|c|}
\hline blo & Cell Physiol Biochem 2012;30:173-186 & \\
\hline and Rinchomistn & $\begin{array}{l}\text { DOI: } 10.1159 / 000339056 \\
\text { Published online: June } 18,2012\end{array}$ & $\begin{array}{l}\text { (C) } 2012 \text { S. Karger AG, Basel } \\
\text { www.karger.com/cpb }\end{array}$ \\
\hline & $\begin{array}{l}\text { Viñuales/Gascón/Barranquero/Osada/Rodríguez- } \\
\text { Absorption }\end{array}$ & di: IL-1 $1 \beta$ on Galactose \\
\hline
\end{tabular}

Fig. 4. Effect of $0.5 \mu \mathrm{g} \mathrm{kg}^{-1}$ bw IL-1 $\beta$ on $0.1 \mathrm{mM}$ D-galactose uptake by brush border membrane vesicles (BBMVs) at different times. The vesicles were prepared from control and IL-1 $\beta$ treated rabbitjejunum. The results are expressed as absolute uptakes in pmol per mg membrane protein and represent the mean and SEM of the data obtained in six animals (three determinations per point). ${ }^{*} p<0.05$ compares results obtained in treated with control.
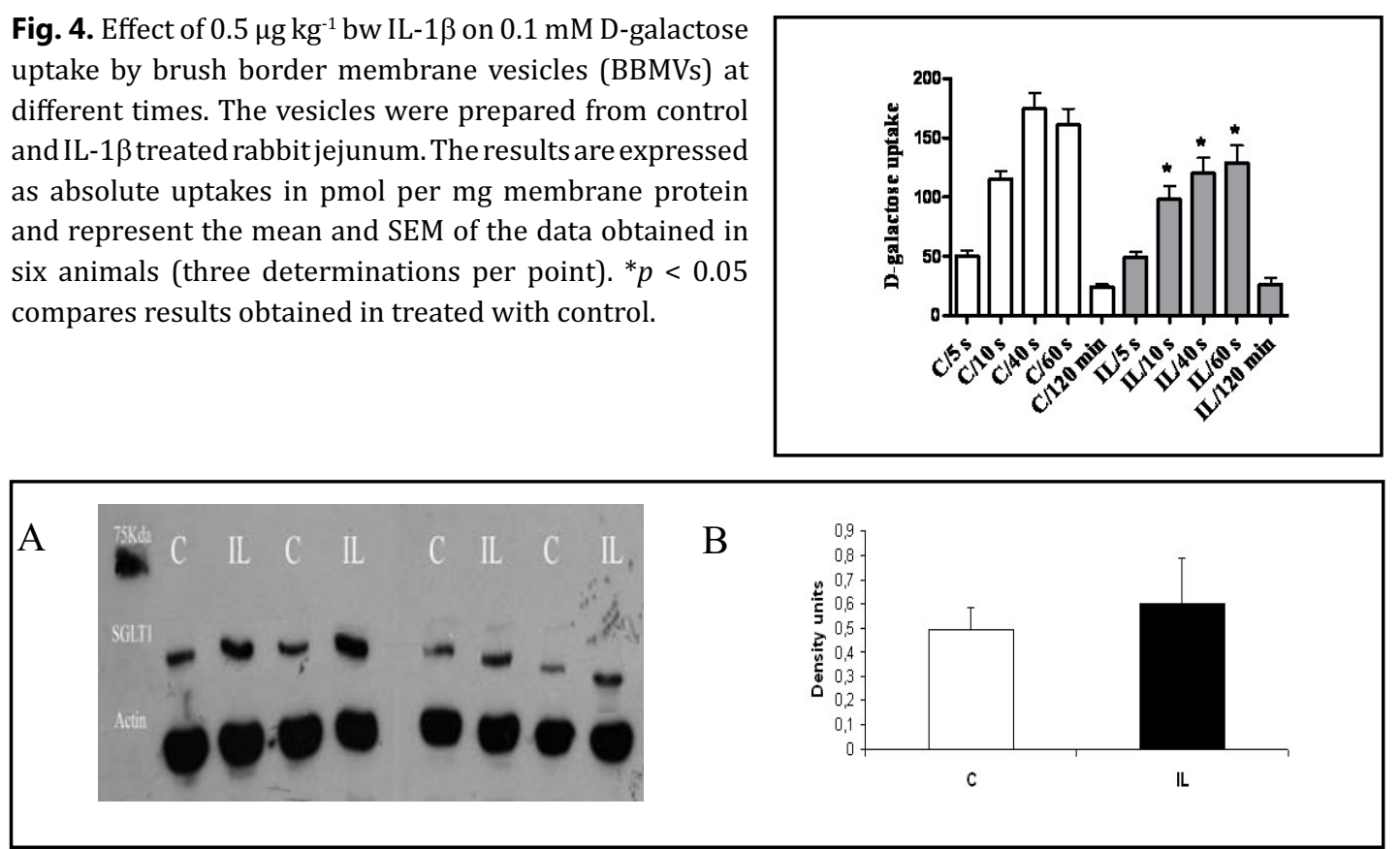

Fig. 5. Effect of $0.5 \mu \mathrm{gg}^{-1}$ bw IL-1 $\beta$ on SGLT1 expression in BBMV. The vesicles were obtained from jejunum of control and treated animals. a) The SGLT1 antibody recognized specifically an immunoreactive protein of about $70 \mathrm{kDa}$ in control (C) and treated (IL) animals. Actin was used as a loading control of total protein on the electrophoresis gel. b) Relative abundance of SGLT1 protein measured by Density. (INT $\mathrm{mm}^{-2}$ ). The preparations of intestinal vesicles per animal of each group $(\mathrm{n}=4)$ were prepared and analyzed in triplicate.

mucosal side.

The $\mathrm{Na}^{+}$-gradient in the enterocyte is necessary to $\mathrm{Na}^{+}$-dependent transport of sugars and is maintained by the $\mathrm{Na}^{+} / \mathrm{K}^{+}$-ATPase located in the basolateral border. Therefore, the effect of IL on the activity of this ATPase was studied in order to determine if the cytokine could inhibit the active D-galactose transport in this way. The results (Fig. 2) showed that IL$1 \beta$ did not alter the activity of this protein neither the electrogenic cellular $\mathrm{Na}^{+}$gradient.

To confirm that IL-1 $\beta$ was acting on the luminal side of the enterocytes, mucosal to serosal (Jm-s), and serosal to mucosal (Js-m) fluxes of $1 \mathrm{mM}$ D-galactose were measured in jejunum segments from control and IL-1 $\beta$ treated animals. For the treated animals, the mucosal to serosal sugar flux was decreased (around 30\%), but the cytokine failed to modify the serosal to mucosal flux (Fig. 3). These results suggest that IL-1 $\beta$ acts on SGLT1 transporter.

Studies on brush border membrane. To verify whether IL-1 $\beta$ is able to induce changes in the $\mathrm{Na}^{+}$-sugar cotransporter, we first examined the effect of the IL on D-galactose uptake with brush border membrane vesicles (BBMV). Two experiment groups were established, one with vesicles from jejunum of control animals and the second group with vesicles from small intestine of treated animals with $0.5 \mu \mathrm{g} \mathrm{kg}{ }^{-1} \mathrm{IL}-1 \beta$ for $90 \mathrm{~min}$. We performed galactose uptakes in purified BBMV at different incubation times: 5, 10, 40, $60 \mathrm{~s}$ and $120 \mathrm{~min}$. Sugar uptake was decreased significantly in specimens from the treated animals at 10,40 and 60 s. Equilibrium uptake values (120 min) and small times ( $5 \mathrm{~s}$ ) did not differ between control and treated animals (Fig. 4).

The next question addressed was whether the direct cytokine effect on SGLT1 could be due to reduced amounts or intrinsic activity of the transporter at the brush border. SGLT1 is a transporter located in the brush border of apical membrane, and transports glucose and galactose from the intestinal lumen into the cytosol. To measure SGLT1 levels in BBMV from control and IL-1 $\beta\left(0.5 \mu \mathrm{g} \mathrm{kg}^{-1}\right)$ treated animals, a Western blot analysis was performed. The 


\section{Cellular Physiology Cell Physiol Biochem 2012;30:173-186 \\ \begin{tabular}{ll|l} 
and BiOChemistry & DOI: 10.1159/000339056 & Published online: June 18, 2012 S. Karger AG, Basel \\
\cline { 2 - 3 } Viñuales/Gascón/Barranquero/Osada/Rodríguez-Yoldi: IL-1 3 on Galactose Intestinal
\end{tabular} Absorption}

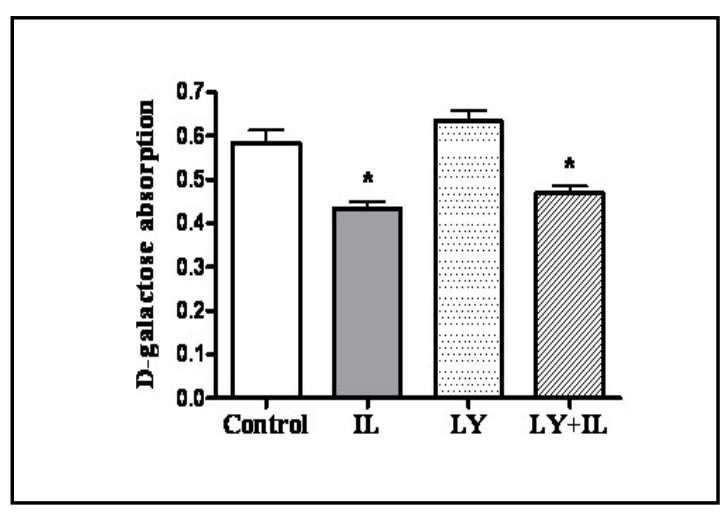

Fig. 6. Effect of LY-294002 on the inhibition of Dgalactose absorption by $0.5 \mu \mathrm{gg}^{-1}$ bw Il-1 $\beta$. LY294002 (LY: PI3K inhibitor) was used at $0.25 \mathrm{mg}$ $\mathrm{kg}^{-1}$ bw. The inhibitor was administrated iv $15 \mathrm{~min}$ before IL-treatment. Uptake of $0.5 \mathrm{mM}$ D-galactose was measured for $3 \mathrm{~min}$ in everted intestinal rings from control and IL-treatment animals. Results are expressed as $\mu \mathrm{mol} D$-galactose per $\mathrm{g}$ tissue. Each value represents the mean and SEM of the data obtained in six animals with six determinations per animal. ${ }^{*} p<0.05$ with respect to the control animals.

Fig. 8. Effect of $I_{20}$ and GF-109203 on the inhibition of D-galactose absorption by $0.5 \mu \mathrm{g} \mathrm{kg}^{-1} \mathrm{bw}$ Il-1 $\beta . \mathrm{IP}_{20}$ (IP: PKA inhibitor) was used at $0.155 \mathrm{mg} \mathrm{kg}^{-1} \mathrm{bw}$ and GF-109203X (GF: PKC inhibitor) was used at $500 \mathrm{ng}$ $\mathrm{kg}^{-1} \mathrm{bw}$. The inhibitors were administrated iv $15 \mathrm{~min}$ before IL-treatment. Uptake of $0.5 \mathrm{mM}$ D-galactose was measured for $3 \mathrm{~min}$ in everted intestinal rings from control and IL-treatment animals. Results are expressed as $\mu \mathrm{mol} \mathrm{D}$-galactose per $\mathrm{g}$ tissue. Each value represents the mean and SEM of the data obtained in six animals with six determinations per animal. ${ }^{*} p<0.05$ with respect to the control animals. $\# p<0.05$ with respect to the IL-animals.

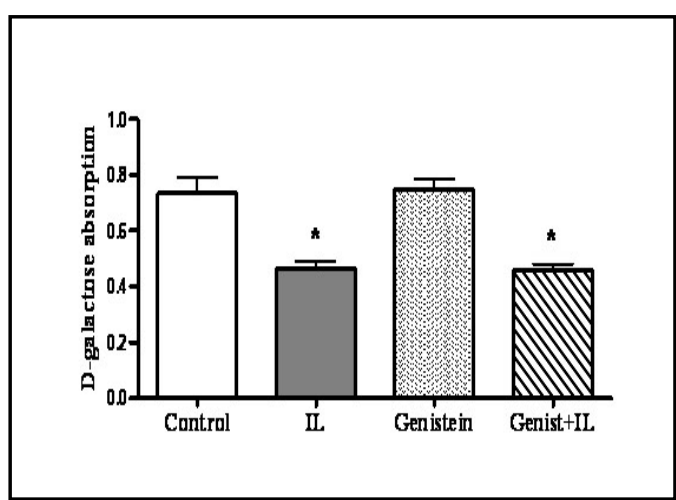

Fig. 7. Effect of genistein on the inhibition of D-galactose absorption by $0.5 \mu \mathrm{g} \mathrm{kg}^{-1}$ bw Il- $1 \beta$. Genistein (PTK inhibitor) was used at $0.19 \mathrm{mg} \mathrm{kg}$ ${ }^{1} \mathrm{bw}$. The inhibitor was administrated iv $15 \mathrm{~min}$ before IL-treatment. Uptake of $0.5 \mathrm{mM}$ D-galactose was measured for $3 \mathrm{~min}$ in everted intestinal rings from control and IL-treatment animals. Results are expressed as $\mu \mathrm{mol}$ D-galactose per $\mathrm{g}$ tissue. Each value represents the mean and SEM of the data obtained in six animals with six determinations per animal. ${ }^{*} p<0.05$ with respect to the control animals.

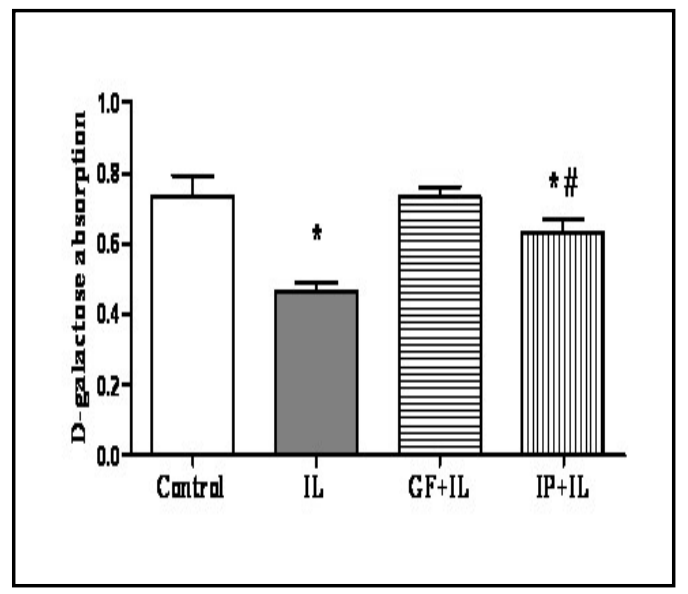

SGLT1 antibody recognized a single 70-kDa band in control and IL-1 $\beta$ BBMs (Fig. 5a). The densitometric analysis for SGLT1, normalized to actin levels, was performed in six separate experiments. The results have shown an increase, no significant, of SGLT1 protein level by IL-1 $\beta$ (Fig. 5b).

\section{Cellular factors mediating the cytokine inhibitory effect on galactose intestinal absorption}

IL-1 plays a major role in inflammation and autoimmunity through activation of nuclear factor kB (NF- $\mathrm{kB})$ and MAPKs [21].

In previous studies of our group, intracellular signaling pathways associated with protein kinases were found to be involved in the effect of LPS and TNF- $\alpha$ on intestinal absorption of nutrients in rabbits [17-19, 22-24]. With the purpose to increase these results, specific kinase inhibitors were used to investigate whether some kinase pathways might also be involved in IL-1 $\beta$ on intestinal D-galactose absorption. Intravenous injection of $0.25 \mathrm{mg} \mathrm{kg}^{-1} \mathrm{bw}$ of LY- 


\section{Cellular Physiology $\quad$ Cell Physiol Biochem 2012;30:173-186

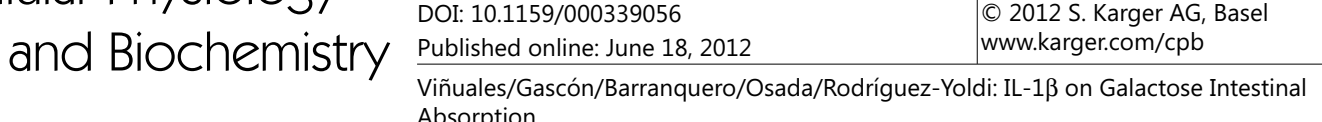

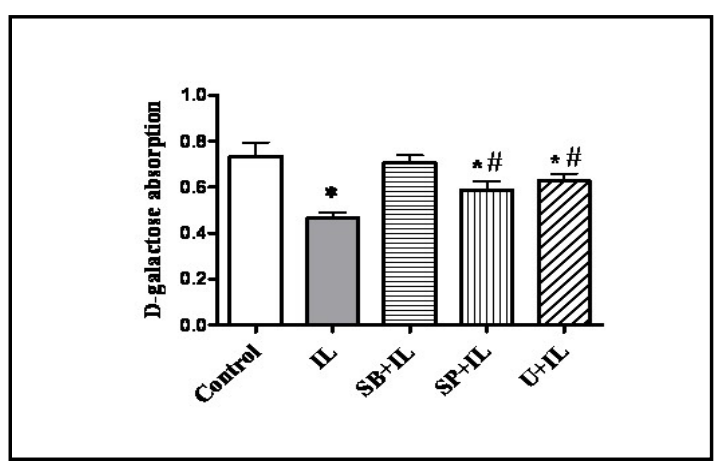

Fig. 9. MAP kinase inhibitors protect D-galactose absorption from $0.5 \mu \mathrm{g} \mathrm{kg}^{-1}$ bw IL-1 $\beta$ inhibition. The inhibitors were administered iv $15 \mathrm{~min}$ before cytokine treatment. SB-203580 (SB: p38 kinase inhibitor) was used at $30 \mu \mathrm{g} \mathrm{kg}^{-1} \mathrm{bw}, \mathrm{SP}-600125$ (SP: JNK inhibitor) was used at $25 \mathrm{\mu g} \mathrm{kg}^{-1}$ bw and U-0126 (U: MEK1/2 inhibitor/ was used at $27 \mu \mathrm{g} \mathrm{kg}^{-1} \mathrm{bw}$. The uptake of $0.5 \mathrm{mM}$ D-galactose was measured for 3 min in everted intestinal rings from control and IL$1 \beta$-treated animals. Results are expressed as $\mu \mathrm{mol} D$ galactose per g tissue. Each value represents the mean and SEM of the data obtained in six animals with six determinations per animal. ${ }^{*} p<0.05$ with respect to the control animals. $\# p<0.05$ with respect to the ILanimals.

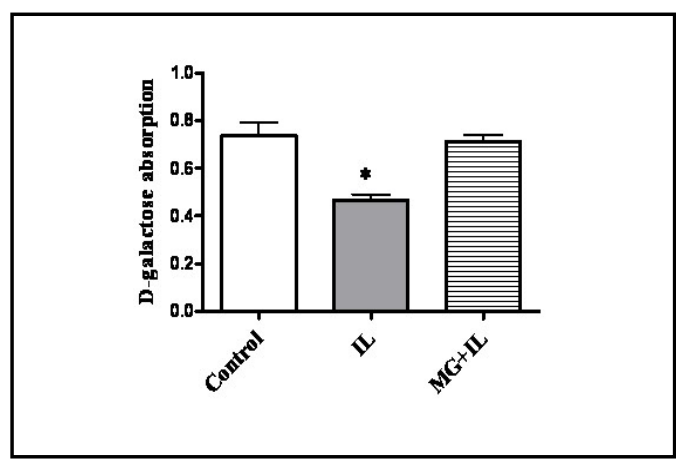

Fig. 10. Proteasome inhibition by MG-132 (MG) prevents D-galactose absorption inhibition by 0.5 $\mu \mathrm{g} \mathrm{kg}^{-1}$ bw Il-1 $\beta$ for 90 min. MG-132 was injected iv $15 \mathrm{~min}$ before IL-treatment at dose of $250 \mu \mathrm{g}$ $\mathrm{kg}^{-1}$ bw. The uptake of $0.5 \mathrm{mM}$ D-galactose was measured for $3 \mathrm{~min}$ in everted intestinal rings from control and IL-1 $\beta$-treated animals. Results are expressed as $\mu \mathrm{mol}$ D-galactose per $\mathrm{g}$ tissue. Each value represents the mean and SEM of the data obtained in six animals with six determinations per animal. ${ }^{*} p<0.05$ with respect to the control animals.

294002, a PI3K inhibitor [25] (Fig. 6) or $0.19 \mathrm{mg} \mathrm{kg}^{-1}$ body wt of genistein, a PTK inhibitor [26] (Fig. 7) for $15 \mathrm{~min}$ before IL- $\beta$ treatment, did not reduced the cytokine inhibitory effect. None of these inhibitors altered the sugar uptake in control animals (Fig. 6 and 7). On the contrary, the intravenous injection of the PKC inhibitor, GF-109203X, or the PKA inhibitor, $\mathrm{IP}_{20}$, at 500 ng kg-1 bw and $0.155 \mathrm{mg} \mathrm{kg}^{-1} \mathrm{bw}$, respectively [16], showed a significant reduction in IL-1 $\beta$ inhibition on $0.5 \mathrm{mM}$ D-galactose absorption as shown in Fig. 8. The reduction was total with GF-109203X and about 30\% in the case of $\mathrm{IP}_{20}$. The involvement of MAP kinases pathways was equally tested at doses previously verified for this animal model [18]. In this regard, SB-203580 (30 $\mathrm{g} \mathrm{kg} \mathrm{k}^{-1} \mathrm{bw}$ ) a selective inhibitor of p38 MAPK was injected intravenously, 15 min prior to IL-1 $\beta$ treatment. At least $93 \%$ of cytokine inhibition on sugar absorption was alleviated by SB-203580 (Fig. 9). Applying a similar protocol, SP-600125 (25 $\left.\mu \mathrm{g} \mathrm{kg}^{-1} \mathrm{bw}\right)$ was used to test the contribution of JNK to IL-1 $\beta$ effect. The results shown in Figure 9 indicate that this inhibitor antagonized the cytokine inhibition about $20 \%$. Finally, $27 \mu \mathrm{g} \mathrm{kg}-1$ bw of U-0126, an inhibitor of MEK1 and MEK2 reverted the cytokine inhibitory effect about 25\% (Fig. 9). Collectively, these results indicate that PKC, PKA and MAP kinases pathways are involved in the inhibition of galactose absorption mediated by this IL-1 $\beta$.

Relation between $N F-\kappa B$ factor and Il-1 $\beta$ effect on galactose absorption

Toll-like receptor (TLR)-interleukin-1 (IL-1) receptor (IL-1R) superfamilies, cause activation of the IkB kinase (IKK) complex. The activated IKK complex, catalyzes the phosphorylation of IkBs, polyubiquitination and subsequent degradation by the $26 \mathrm{~S}$ proteasome. Translocation of NF- $\mathrm{KB}$ to the nucleus is then observed. Most of the biological effects of IL-1 take place in cells following nuclear translocation of NF- $\kappa B$ [27]. In well known that IkB phosphorylation at serine residue 32 and 36 is induced both by TNF- $\alpha$ and IL-1 [28]. 


\section{Cellular Physiology Cell Physiol Biochem 2012;30:173-186

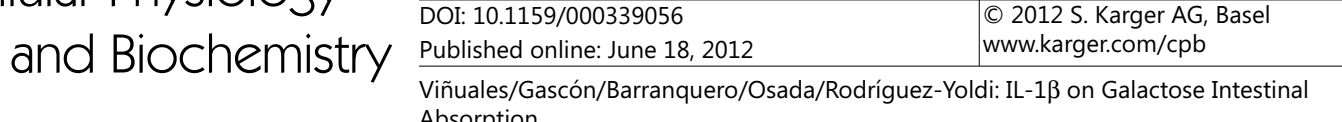

In this way, the possible proteasome involvement in the IL-1 $\beta$ inhibitory effect was also evaluated using MG-132, a potent cell-permeable proteasome inhibitor at $250 \mathrm{\mu g} \mathrm{kg}^{-1} \mathrm{bw}$ [18]. Our results indicated that MG-132 treatment before the IL-1 $\beta$ injection completely suppressed its effect on the intestinal absorption of D-galactose (Fig. 10) showing the possible implication of NF-kB factor in the inhibitory cytokine effect.

\section{Discussion}

A variety of bacteria and their excreted/secreted products have direct effects on epithelial ion transport and permeability $[29,30]$ and release of cytokines during bacterial infection may impact directly on epithelial function [31]. In this way, the administration of LPS is known to be a strong inducer of TNF and IL-1 [32] and IL-1 $\beta$ has a special role in the modulation of other inflammatory cytokine such as IL-8 or IL-6 [33]. The cytokines play an essential role in inflammation and are mainly produced upon activation of monocytemacrophages [34].

It is well-known that LPS and IL-1, IL- 6 and TNF- $\alpha$ induce a multitude of host responses in the gut. Previous studies in our laboratory have shown that after intravenous administration of LPS, the intestinal absorption of L-leucine, D-galactose and D-fructose was inhibited. The endotoxin effect could be produced by the secretagogue action of TNF- $\alpha$ on the gut, also implying protein kinases and other mediators such as nitric oxide (NO) and prostaglandins $[16-19,35,36]$. On the other hand, recent studies in our laboratory have shown that NO is involved in the IL-1 $\beta$ action on D-fructose intestinal transport [15]. In this study, we have proved that sepsis achieved by intravenous administration of IL-1 $\beta$ inhibits D-galactose mucosal intestinal transport and does not affect significantly SGLT1 protein levels in the BBM. Several transduction pathways are activated during the inflammatory processes, and they affect the function of the small intestine. The PKC, PKA, MAPKs and NF- $\mathrm{BB}$ transduction pathways could be related to the inhibition of galactose transport in the sepsis state induced by IL-1 $\beta$.

Fever is a systemic inflammatory response, and several endogenous pyrogens have been identified including the proinflammatory cytokine IL-1 [7]. In our work, following the injection of IL-1 $\beta\left(0.5 \mu \mathrm{g} \mathrm{kg}^{-1} \mathrm{bw}\right)$ in normal rabbits, there was a significant temperature increase at 90 min $(\sim 1.05)$ (Table 2). Our results exclude any impact of IL-1 $\beta$ through the induction of apoptosis. Morphologically, cells undergoing apoptosis show alterations of cell volume, cytoplasmic organelles, and microvilli. IL-1 $\beta$ treatment in this study had none of the above mentioned effects on the structure of brush border membrane compared with control rabbits (Fig. 1a and b). However, funcional alterations of the gut were induced by IL-1 $\beta$ administration in rabbits. D-galactose absorption was significantly inhibited in the small intestine after IL injection of low $\left(0.05 \mu \mathrm{g} \mathrm{kg}^{-1} \mathrm{bw}\right)$ and high $\left(0.5 \mu \mathrm{g} \mathrm{kg}{ }^{-1} \mathrm{bw}\right)$ doses of cytokine (Table 1). Likewise, IL-1 $\beta$ inhibited Jm-s and sugar across purified BBMV (Fig. 3 and 4) indicating that the cytokine affected the transport at the luminal side of the cell. Moreover, studies with phlorizin, a competitive inhibitor of $\mathrm{Na}^{+}$-glucose transport, prove that the cytokine not modify sugar simple diffusion. Therefore, IL-1 $\beta$ treatment does seem to alter $\mathrm{Na}^{+}$- galactose cotransporter located at the mucosal side. Indee, the Js-m and the $\mathrm{Na}^{+} /$ $\mathrm{K}^{+}$-ATPase activity were unchanged by IL-treatment (Fig. 2 and 3). On the other hand, the SGLT1 levels neither were changed significantly by IL-treatment (Fig. $5 a$ and b).

The regulation of cell function by ligands acting on membrane receptors (such as IL1) generates intracellular signals and second messenger signalling [37-39]. Inflammatory mediators, like cytokines, released during acute and chronic diseases activate several intracellular signalling cascades including the MAPK signal transduction pathway [40]. MAPKs exerts their effect through serine/threonine phosphorylation of their substrates, including the transcript factors and genes. It has been shown that tumour necrosis factor (TNF) and interleukin-1 (IL-1) activate p38 MAPK, JNK and p42/44 MAPK [41, 42]. Ikeda et al. [43] also found that Shiga toxin activates p38 MAP kinases through cellular $\mathrm{Ca}^{2+}$ increase. Moreover, several studies have shown that pharmacological inhibitors of MAPK strongly 


\section{Cellular Physiology Cell Physiol Biochem 2012;30:173-186 \begin{tabular}{ll|l}
\multirow{2}{*}{ and Biochemistry } & DOI: 10.1159/000339056 & $\begin{array}{l}\text { C 2012 S. Karger AG, Basel } \\
\text { www.karger.com/cpb }\end{array}$ \\
\cline { 2 - 3 } & Viñuales/Gascón/Barranquero/Osada/Rodríguez-Yoldi: IL-1 $\beta$ on Galactose Intestinal
\end{tabular}}

affect the production of inflammatory cytokines [44, 45]. Mckay et al., in 2007 [25] indicated as PI3K and PKC inhibitors prevented the increase in paracellular permeability induced by $E$. coli. PI3K pathway has been implicated in a wide array of biological and pathophysiological responses. There is evidence that PI3K, PDK1 and Akt kinases are important components of the molecular mechanisms of diseases such as diabetes and chronic inflammation, as well as cancer [46].

The small intestine plays a primary role in the transport of nutrients, electrolytes, and water and their mechanism of absorption can be alter when some proteins are activated. Likewise, in previous studies [47] indicated that the regulation of $\mathrm{Na}^{+}$-glucose cotransporter expression by protein kinases occurs largely by regulated exo- and endocytosis, and that the effect of the protein kinases is indirect and determined by critical domains in the cotransporter. They suggest that PKA and PKC regulate rabbit SGLT1 activity by modulating the number of cotransporters in the intestinal plasma membrane. Other studies have suggested a role for PKC in SGLT1-mediated glucose transport as both a positive and negative regulator of SGLT1 expession in cell culture $[48,49]$. PKC also plays a role in SGLT1-mediated glucose transport in transfected oocytes [50]. As well, the activation of PKC altered electrolyte transport in vivo in rat distal colon [51], fructose transport across the jejunum brush border in rat [52], and Larginine, L-alanine, and sodium-glucose-cotransport in cell lines [53-55]. In this way, Helliwell et al. conclude that GLUT2-mediated fructose absorption is regulated through PI3-kinase and mammalian target of rapamycin-dependent pathways, which control phosphorylation of PKC $\beta I I$ and its substrate-induced turn-over and ubiquitin-dependent degradation [56].

Epidermal Growth Factor (EGF) has been reported to upregulate arginine transport in Caco-2 cells in a PKC-dependent manner [53]. The stimulatory effect of EGF on jejunal glucose transport in rabbits is mediated at least in part by PKC and PI 3-kinase [57]. Cui et al [58] hypothesized that the PI3-kinase/Akt signalling pathway plays a major role in the fructose-induced upregulation of GLUT5 activity.

In the present work, the inhibition of galactose absorption by IL-1 $\beta$ is not reduced by the PI3K and PTK inhibitors (LY-294002 and genistein, respectively) (Fig. 6 and 7). This fact suggests that these ways, in the present experimental model, are not involved in the IL-1 $\beta$ action. However, PKC inhibition by GF-109203X protected intestinal D-galactose absorption from IL-induced inhibition, suggesting that part of cytokine's effect is under PKC control.

Cyclic AMP is a known second messenger involved in fluid and electrolyte secretion in the small intestine [59]. Moreover, cAMP and PKA pathway were shown to alter the GLUT5 mRNA abundance and translation in the human enterocytic cell line Caco-2/TC7 cells [60, 61].

PKA inhibition by IP ${ }_{20}$ partly reversed IL-1 $\beta$ inhibition of galactose absorption suggesting a possible role for PKA (Fig. 8).

Shikhman et al., 2004 [62] showed that IL-1 $\beta$-stimulated glucose transport is PKC and p38 MAP-activation-dependent and is accompanied by increased expression and membrane incorporation of different glucose transporters and the type of transporter affected depends on the tissue. Moreover, studies of Helliwell et al. [52] indicate that there is a extensive crosstalk between the ERK, p38 and PI 3-kinase pathways in their control of brush-border fructose transport by modulation of both the levels and intrinsic activities of GLUT5 and GLUT2. In our research, the inhibition of sugar uptake after IL-1 $\beta$ treatment is significantly reduced by the MAPKs inhibitors (SB-203580, SP-600125 and U-0126) indicating that this pathway could be involved in the action of the cytokine on galactose absorption.

Frobose et al. 2007 [21] show that IL-1 plays a major role in inflammation and autoimmunity through activation of nuclear factor kB (NF-êB) and MAPKs.

The nuclear factor (NF)- $\mathrm{kB}$ is one member of a ubiquitously expressed family of Relrelated transcription factors that serve as critical regulators of many genes, including those of pro-inflammatory cytokines and other inflammatory mediators $[63,64]$. The translocation and activation of NF- $\mathrm{KB}$ in response to various stimuli such as lipopolysaccharide-endotoxin (LPS) and cytokines are sequentially organized at the molecular level. In its inactive state, the heterodimeric NF- $\kappa B$, is present in the cytoplasm associated with its inhibitory protein, IkB [49]. Upon stimulation, IkB, the major cytosolic inhibitor of NF- $\kappa B$ [63], undergoes 


\section{Cellular Physiology Cell Physiol Biochem 2012;30:173-186

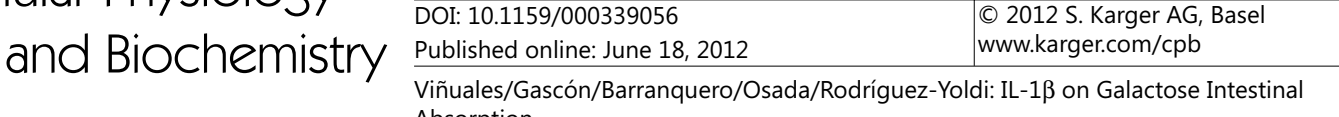

phosphorylation on serine/threonine residues (e.g. MAPKs), ubiquitination and subsequent proteolytic degradation by the proteasome complex and allowing the nuclear translocation of the complex. This sequential propagation of signalling ultimately results in the release of $\mathrm{NF}-\kappa \mathrm{B}$ subunits from the IkB inhibitor, thus promoting the translocation and initiation of gene transcription $[63,64]$. With the purpose to elucidate if this way could be implicated in the IL$1 \beta$ effect, a pretreatment of rabbits with MG-132, a specific inhibitor of the proteasome was used. This inhibitor seems to abolish cytokine effects on sugar absorption (Fig. 10). From our results, SGLT1 could be controlled by the proteasome that by indirect mechanisms, i.e. through NF- $\mathrm{BB}$ activation, would alter SGLT1 activity.

In summary, these results probe that PKC, PKA, MAP kinases and proteasome are implicated in the inhibitory effect of IL-1 $\beta$ on D-galactose absorption. These ways could modulate the SGLT1 functionality and contribute to the inhibition.

\section{Acknowledgements}

This work was supported by grants from FIS and ISCIII CB06/03/1012, Departamento de Ciencia, Tecnología y Universidad del Gobierno de Aragón (Spain) and FSE: A-32 and PI017/09.

\section{References}

1 Bachmann MF, Kopf M: Balancing protective immunity and immunopathology. Curr Opin Immunol 2002;14:413-419.

2 Powanda MC, Beisel WR: Metabolic effects of infection on protein and energy status. J Nutr 2003;133:322S$327 \mathrm{~S}$.

3 Riedemann NC, Guo RF, Hollmann TJ, Gao H, Neff TA, Reuben JS, Speyer CL, Sarma JV, Wetsel RA, Zetoune FS, Ward PA: Regulatory role of C5a in LPS-induced IL-6 production by neutrophils during sepsis. FASEB J 2004;18:370-372.

4 Al-Sadi RM, Ma TY: I-1 $\beta$ causes an increase in intestinal epithelial tight junction permeability. J Immunol 2007;178: 4641-4649.

5 Ligunsky M, Simon PL, Karmeli F, Rachmilewitz D: Role of interleukin 1 in inflammatory bowel diseaseenhanced production during active disease. Gut 1990;31:686-689.

6 Dinarello CA: Immunological and inflammatory functions of the interleukin-1 family. Annu Rev Immunol 2009;27:519-550.

7 Dinarello CA: Interleukin-1 $\beta$. Crit Care Med 2005;33:S460-S462.

8 Isaacs KL, Sartor RB, Haskill S: Cytokine messenger RNA profiles in inflammatory bowel disease mocosa detected by polymerase chain reaction amplification. Gastroenterology 1992;103:1587-1595.

9 Reinecker HC, Steffen M, Doehn C, Petersen J, Pfluger I, Voss A, Raedler A: Proinflammatory cytokines in intestinal mucosa. Immunol Res 1991;10:247-248.

10 Bértolo C, Barrenetxe J, Barber A, Lostao MP: Cytokine effect on intestinal galactose absorption. J Physiol Biochem 2002;58: 61-62.

11 Kreydiyyeh SI, Haddad JJE, Garabedian B-S: Interleukin-1 beta inhibits the intestinal transport of [ $\left.{ }^{14} \mathrm{C}\right]$ 3-omethylglucose in the rat. Life Sci 1998;63:1913-1919.

12 Chang EB, Musch MW, Mayer L: Interleukin 1 and 3 stimulate anion secretion in chicken intestine. Gastroenterology 1990;98:1518-1524.

13 Chiossone DC, Simon PL, Smith PL: Interleukin-1: effects on rabbit ileal mucosal ion transport in vitro. Eur J Pharmacol 1990;180:217-228.

14 Hardin J, Kroeker K, Chung B, Gall DG: Effect of proinflammatory interleukins on jejunal nutrient transport. Gut 2000;47:184-191. 


\section{Cellular Physiology Cell Physiol Biochem 2012;30:173-186

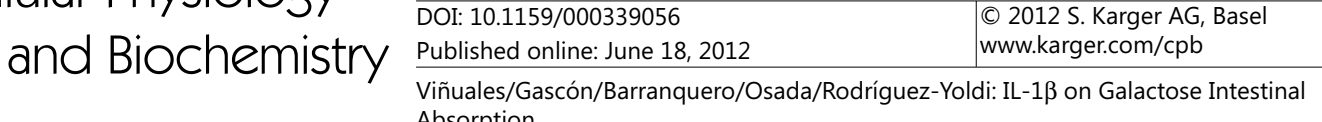

15 García-Barrios A, Guillén N, Osada J, Vazquez CM, Miguel-Carrasco JL, Rodríguez-Yoldi MJ: Nitric Oxide involved in the IL-1 $\beta$-induced inhibition of fructose intestinal transport. J Cell Biochem 2010;111:13211329.

16 Amador P, García-Herrera J, Marca MC, de la Osada J, Acín S, Navarro MA, Salvador MT, Lostao MP, Rodríguez-Yoldi MJ: Intestinal D-Galactose transport in an endotoxemia model in the rabbit. J Membr Biol 2007;215:125-133.

17 Amador P, García-Herrera J, Marca MC, de la Osada J, Acín S, Navarro MA, Salvador MT, Lostao MP, Rodríguez-Yoldi MJ: Inhibitory effect of TNF- $\alpha$ on the intestinal absorption of Galactose. J Cell Biochem 2007;101:99-111.

18 García-Herrera J, Marca MC, Brot-Laroche E, Guillén N, Acín S, Navarro MA, De la Osada J, Rodríguez-Yoldi MJ: Protein kinases, TNF- $\alpha$, and proteasome contribute in the inhibition of fructose intestinal transport by sepsis in vivo. Am J Physiol-Gastrointest Liver Physiol 2008;294:G155-G164.

19 Abad B, Mesonero JE, Salvador MT, García-Herrera J, Rodríguez-Yoldi MJ: The administration of lipopolysaccharide, in vivo, induces alteration in L-leucine intestinal absorption. Life Sci 2001;70:615-618.

20 Wright EM, Hirayama BA, Loo DF: Active sugar transport in health and disease. J Internal Med 2007;261:32-43.

21 Frobose H, Ronn SG, Heding PE, Mendoza H, Cohen P, Mandrup-Poulsen T, Billestrup N: Suppressor of cytokine signalling- 3 inhibits Interleukin-1 signaling by targeting the TRAF-6/TAK1 Complex. Mol Endocrinol 2006;20:1587-1596.

22 Abad B, Mesonero JE, Salvador MT, García-Herrera J, Rodríguez-Yoldi MJ: Cellular mechanism underlying LPS-induced inhibition of in vitro L-leucine transport across rabbit jejunum. J Endotox Res 2002;8:127133.

23 García-Herrera J, Abad B, Rodríguez-Yoldi MJ: Effect of lipopolysaccharide on D-fructose transport across rabbit jejunum. Inflamm Res 2003;52:177-184.

24 Amador P, Marca MC, García-Herrera J, Lostao MP, Gillén N, de la Osada J, Rodríguez-Yoldi MJ: Lipopolysaccharide induces inhibition of Galactose intestinal transport in rabbits in vitro. Cell Physiol Biochem 2008;22:715-724.

25 McKay DM, Watson JL, Wang A, Caldwell J, Prescott D, Ceponis PMJ, Di Leo V, Lu J: Phosphatidylinositol 3-kinase is a critical mediator of interferon-ã-induced increases in enteric epithelial permeability. J Pharmacol Exp Ther 2007;320:1013-1022.

26 Akiyama T, Ishida J, Nakagawa S, Ogawara H, Watanabe S, Itoh N, Shibuya M, Fukami Y: Genistein, a specific inhibitor of tyrosine-specific protein kinases. J Biol Chem 1987;262:5592-5595.

27 Bonizzi G, Karin M: The two NF-kB activation pathways and their role in innate and adaptive immunity. Trends Immunol 2004;25:280-288.

28 Rubinstein M, Dinarello CA, Oppenheim JJ, Hertzog P: Recent advances in cytokines, cytokine receptors and signal transduction. Cytokine Growth Factor Rev 1998;9:175-81.

29 Lewis SA, Berg JR, Kleine TJ : Modulation of epithelial permeability by extracellular macromolecules. Physiol Rev 1995;75:561-589.

30 Sears C, Kaper J: Enteric bacterial toxins: mechanisms of action and link-age to intestinal secretion. Microbiol Rev 1996;60:167-215.

31 McKay DM, Baird AW: Cytokine regulation of epithelial permeability and ion transport. Gut 1999; 44: $283-$ 289.

32 Miller AJ, Hopkins SJ, Luheshi GN: Sites of action of IL-1 in the development of fever and cytokine responses to tissue inflammation in the rat. Brit J Pharmacol 1997;120:1274-1279.

33 Eskan MA, Benakanakere MR, Rose BG, Zhang P, Zhao J, Stathopoulou P, Fujioka D, Kinane DF: Interleukin$1 \beta$ modulates proinflammatory cytokine production in human epithelial cells. Infect Immun 2008;76:20802089.

34 Netea MG, Simon A, van de Veerdonk F, Kullberg B-J, Van der Meer JWM, Joosten LAB: IL-1 $\beta$ processing in host defense: beyond the inflammasomes. PloS Pathog 2010;6:1-9.

35 Abad B, Mesonero JE, Salvador MT, García-Herrera J, Rodríguez-Yoldi MJ: Tumor necrosis factor- $\alpha$ mediates inhibitory effect of lipopolysaccharide on L-leucine intestinal uptake. Dig Dis Sci 2002;46:1316-1322.

36 García-Herrera J, Navarro MA, Marca MC, De la Osada J, Rodríguez-Yoldi MJ: The effect of tumor necrosis factor- $\alpha$ on D-fructose intestinal transport in rabbits. Cytokine 2004;25:21-30.

37 O'Neill J, Greene C: Signal transduction pathways activated by the IL-1 receptor family: ancient signaling machinery in mammals, insects and plants. J Leukoc Biol 1998;63:650-657. 


\section{Cellular Physiology Cell Physiol Biochem 2012;30:173-186

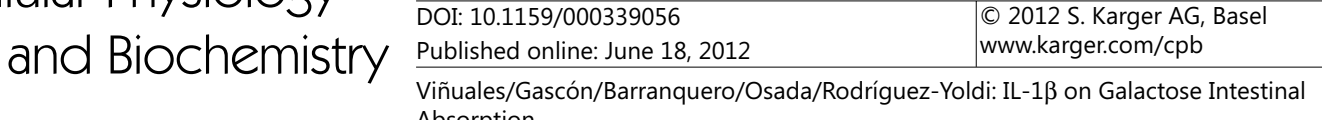

38 Bowie A, O'Neill LAJ: The interleukin-1 receptor Toll-like receptor superfamily: signal generators for proinflammatory interleukins and microbial products. J Leukoc Biol 2000;67:508-514.

39 Chen CC, Chen JJ, Chou CY: Protein Kinase C-alpha but not p44/42 Mitogen-Activated Protein Kinase, p38, or c-Jun NH2-Terminal Kinase Is Required for Intercellular Adhesion Molecule-1 Expression Mediated by Interleukin-1 $\beta$ : Involvement of Sequential Activation of Tyrosine Kinase, Nuclear Factor-kB-Inducing Kinase, and IkB Kinase 2. Mol Pharmacol 2000;58:1479-1489.

40 Kyriakis JM, Avruch J: Mammalian mitogen-activate protein kinase signal transduction pathways activated by stress and inflammation. Physiol Rev 2001;81:807-869.

41 Hambleton J, Weinstein SL, Lem L, De Franco AL: Activation of c-Jun N-terminal kinase in bacterial lipopolysaccharide-stimulated macrophages. Proc Nat Acad Sci USA 1996;93:2774-2778.

42 van den Blink B, Branger J, Weijer S, van Deventer SJH, van der Poll T, Peppelenbosch MP: Human endotoxemia activates p38 MAP kinase and p42/44 MAP kinase but not c-Jun- $\mathrm{N}$-terminal kinase. Mol Med 2001;7:755-760.

43 Ikeda M, Gunji Y, Yamasaki S, Takeda Y: Shiga toxin activates p38 MAP kinase through cellular $\mathrm{Ca}^{2+}$ increase in vero cells. FEBS Lett 2000;485:94-98.

44 van den Blink B, Juffermans NP, Hove TT, Schultz MJ, van Deventer SJH, van der Poll T, Peppelenbosch AP: p38 mitogen-activated protein kinase inhibition increases cytokine release by macrophages in vitro and during infection in vivo. J Immunol 2001;166:582-587.

45 Hommes D, Van den Blink B, Plasse T, Bartelsman J, Xu C, Macpherson B, Tytgat G, Peppelenbosch M, van Deventer S: Inhibition of stress-activated MAP kinases induces clinical improvement in moderate to severe Crohn's disease. Gastroenterology 2002;122:7-14.

46 Stein RC: Prospects for phosphoinositide 3-kinase inhibition as a cancer treatment. Endocr Relat Cancer 2001;8:237-248.

47 Wright EM, Hirsch JR, Loo DDF, Zampighi GA: Regulation of $\mathrm{Na}^{+} /$glucose cotransporters. J Exp Biol 1997;200:287-293.

48 Delezay O, Baghdiguian S, Fantini J: The development of $\mathrm{Na}^{+}$-dependent glucose transport during differentiation of an intestinal epithelial cell clone is regulated by PKC. J Biol Chem 1995;279:1253612541.

49 Vayro S, Silverman M: PKC regulates turnover rate of rabbit intestinal $\mathrm{Na}^{+}$-glucose transporter expressed in COS-7 cells. Am J Physiol Cell Physiol 1999;276:C1053-C1060.

50 Hirsch JR, Loo DDF, Wright EM: Regulation of $\mathrm{Na}^{+} /$glucose cotransporter expression by protein kinases in Xenopus laevis oocytes. J Biol Chem 1996;271:14740-14746.

51 Heinke B, Ribeiro R, Diener M: Involvement of calmodulin and protein kinase $\mathrm{C}$ in the regulation of $\mathrm{K}^{+}$ transport by carbachol across the rat distal colon. Eur J Pharmacol 1999;377:75-80.

52 Helliwell PA, Richardson M, Affleck J, Kellett GL: Regulation of GLUT5, GLUT2 and intestinal brush-border fructose absorption by the extracellular signal-regulated kinase, p38 mitogen-activated kinase and phosphatidylinositol 3-kinase intracellular signalling pathways. Implications for adaptation to diabetes. Biochem J 2000;350:163-169.

53 Pan M, Steven BR: Protein kinase C-dependent regulation of L-arginine transport activity in Caco-2 intestinal cells. Biochem Biophys Acta 1995;1239:27-32.

54 Pan M, Stevens BR: Differentiation and protein kinase C dependent regulation of alanine transport via system B. J Biol Chem 1995;270:3582-3587.

55 Vayro S, Silverman M: PKC regulates turnover rate of rabbit intestinal Na+-glucose transporter expressed in COS-7 cells. Am J Physiol Cell Physiol 1999;276:C1053-C1060.

56 Helliwell PA, Rumsby MG, Kellett GL: Intestinal sugar absorption is regulated by phosphorylation and turnover of protein kinase C $\beta I$ II mediated by phosphatidylinositol 3-kinase- and mammalian target of rapamycin-dependent pathways. J Biol Chem 2003;278:28644-28650.

57 Millar GA, Hardin JA, Johnson LR, Gall DG: The role of PI 3-kinase in EGF-stimulated jejunal glucose transport. Can J Phys Pharm 2002;80:77-84.

58 Cui X-L, Schlesier AM, Fisher EL, Cerqueira C, Ferraris RP: Fructose-induced increases in neonatal rat intestinal fructose transport involve the PI3-kinase/Akt signalling pathway. Am J Physiol Gastrointest Liver Physiol 2005;288:G1310-G1320.

59 Field M: Ion transport in rabbit ileal mucosa. II. Effects of cyclic 3', 5'-AMP. Am J Physiol 1971; 221: 992 997. 


\section{Cellular Physiology $\quad$ Cell Physiol Biochem 2012;30:173-186

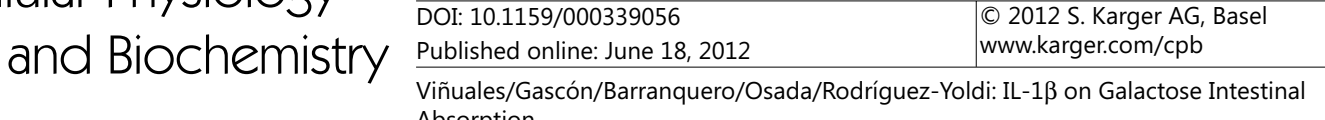

60 Gouyon F, Onesto C, Dalet V, Pages G, Leturque A, Brot-Laroche E: Fructose modulates GLUT5 mRNA stability in differentiated Caco-2 cells: role of cAMP-signalling pathway and PABP (polyadenyllated-binding protein)-interacting protein (paip)2. Biochem J 2003;375:167-174.

61 Mesonero JE, Matosin M, Cambier D, Rodríguez-Yoldi MJ, Brot-Laroche E: Sugar-dependent expresión of the fructose transporter GLUT5 in Caco-2 cells. Biochem J 1995;312:757-762.

62 Shikhman AR, Brinson DC, Lotz MK: Distinct pathways regulate facilitated glucose transport in human articular chondrocytes during anabolic and catabolic responses. Am J Physiol Endocrinol Metab 2004;286: E980- E985.

63 Mercurio F, Manning AM: Multiple signals converging on NF-kappaB. Curr Opin Cell Biol 1999;11:226-232.

64 Haddad JJ, Lauterbach R, Saadé NE, Safieh-Garabedian B, Land SC: Alpha-melanocyte-related tripeptide, Lys-d-Pro-Val, ameliorates endotoxin-induced nuclear factor kappaB translocation and activation: evidence for involvement of an interleukin-1beta193-195 receptor antagonism in the alveolar epithelium. Biochem J 2001;355:29-38. 